\title{
A Formação de Comunidades de Prática no Ensino de Física: Uma Análise a Partir de Grupos de Estudo de Aula
}

\section{The Formation of Communities of Practice in Physics Teaching: An Analysis from Lesson Study Groups}

\author{
Micaías Andrade Rodrigues \\ Brasil \\ Valéria Campos dos Santos \\ Brasil \\ Agnaldo Arroio \\ Brasil
}

O desenvolvimento profissional é algo que tem sido discutido e é considerado elemento chave para a melhoria da educação, ocorrendo, segundo diversos autores, de forma mais efetiva em ações colaborativas. Uma destas formas é através do estudo de aula. $\mathrm{O}$ estudo de aula é uma metodologia japonesa que foi adaptada, em nosso estudo, para ser utilizada em comunidades de prática. Comunidade de prática consiste em um grupo que se reúne para desenvolver maneiras compartilhadas de buscar interesses comuns. Desta forma, foram criados dois grupos com professores e licenciandos em física nos quais foram desenvolvidas, através de estudo de aula, aulas de investigação, as quais foram aplicadas em diferentes turmas, observadas e discutidas pelos pares. Utilizamos os indicadores de presença de comunidades de prática de Wenger para verificarmos se as atividades de estudo de aula propiciaram a formação destas. Como resultados nós verificamos durante os encontros formativos nos dois grupos a existência de 11 dos 14 indicadores citados. Desta forma, podemos concluir que as atividades de estudo de aula realizadas acarretaram na formação de duas diferentes comunidades de prática e estas possibilitaram o desenvolvimento profissional de todos os atores envolvidos.

Palavras-Chave: Ensino de Física; Formação de professores; Comunidade de prática; Estudo de aula.

Professional development is something that has been discussed and is considered a key element for improving education. According to several authors, it occurs more effectively in collaborative actions. One of these ways is through lesson study. Lesson study is a Japanese methodology that was adapted in this paper so that we could use it in communities of practice. Community of practice consists of a group that comes together to develop shared ways of pursuing common interests. In this way, we created two groups with preservice and in-service physics teachers in which research lessons were developed, through lesson study, and applied to different classes, to be observed and discussed by peers. We used Wenger's indicators for the presence of community of 
practice to verify whether the lesson study activities provided formation of communities. As a result, during the formative meetings in both groups, we verified the existence of 11 of the 14 indicators mentioned. Therefore, we can conclude that the lesson study activities carried out resulted in the formation of two different communities of practice that enabled the professional development of all the actors involved.

Keywords: Physics teaching; Teacher education; Community of practice; Lesson study.

\section{Introdução}

No mundo atual, é de suma importância que os professores se atualizem para que o ensino seja contextualizado e desperte o interesse dos alunos. Considerando a prática docente, uma das formas de ocorrer esta atualização é através de atividades colaborativas entre os pares (Fiorentini \& Crecci, 2013; Passos et al., 2006; Van Den Bergh et al., 2014).

Uma possibilidade de fomento ao trabalho coletivo entre os pares ocorre através do Estudo de Aula (EA), que pode apoiar o professor na análise de sua prática almejando seu aperfeiçoamento. A metodologia do Estudo de Aula (EA) tem origem japonesa e tem sido utilizada, em diversos países, como forma de discutir e aprimorar o trabalho do professor em sala de aula (Baptista et al., 2012; Baptista et al., 2014; Saito \& Atencio, 2013; Soto Gómez \& Pérez Gómez, 2015; United, 2009). No Brasil, essa metodologia também vem sendo estudada e relatos apontam uma crescente utilização em pesquisas e práticas de sala de aula (Carrijo Neto, 2014; Coelho et al., 2014; Felix, 2010; Rodrigues, 2019). O EA é uma metodologia utilizada, desde o seu surgimento, na formação de professores, quer em formação inicial, quer em serviço. Nela, o professor e o futuro professor podem refletir sobre as suas (futuras) ações e avaliar como fazer para que suas aulas se tornem mais eficazes, proporcionando um verdadeiro aprendizado aos alunos.

O EA existe no Japão há mais de 100 anos. No entanto, somente apenas ao se tornar o foco da Ninth Conference of the International Congress on Mathematics Education (ICME), em 2002, o EA atraiu a atenção internacional. Como o Japão destaca-se nos resultados da Third International Mathematics and Science Study (TIMSS), alguns países, como os EUA (Lewis et al., 2012; Mitchell, 2014), procuraram compreender como ocorria o ensino no Japão, especialmente de Ciências e Matemática, visto que os resultados deste país eram bem superiores aos da maioria dos países (inclusive os EUA). Após isto, o EA se espalhou para diversos países e ocorreram mais de uma dúzia de conferências e workshops internacionais sobre a temática (Murata, 2011).

Desde então, o EA tem sido amplamente utilizado em vários locais do mundo, como Austrália, Portugal, Inglaterra, Coreia, Malásia, EUA, Suécia etc. No Brasil, este método ainda é pouco conhecido e utilizado, porém, em alguns lugares, como nos Estados Unidos (Saito \& Atencio, 2013) e na Inglaterra (United, 2009), esta metodologia é utilizada como uma das estratégias de governo para melhorar os índices da educação nacional.

Diferentes autores definem e detalham as etapas necessárias para se realizar o EA 
(Fernandez \& Yoshida, 2004; Murata, 2011; Norwich, 2014; United, 2009). De acordo com Murata (2011), o processo do EA se dá através de quatro etapas: escolher os objetivos para a aprendizagem e desenvolvimento do estudante; planejar, colaborativamente, uma "aula de investigação"; observar a "aula de investigação" e coletar dados acerca da aprendizagem e desenvolvimento dos estudantes; e, por fim, usar os dados para refletir sobre aula. A aula de investigação é o nome dado à aula coletivamente produzida pelos pares e que terá a sua aplicação investigada pelas mesmas pessoas que a produziram. Assim, é possível identificar se os objetivos propostos foram alcançados e gerar dados para a discussão posterior acerca dela.

Desta forma, a partir dos passos estabelecidos por Murata (2011), os professores podem definir uma questão de pesquisa compartilhada acerca da aprendizagem dos seus alunos e, após a definição dos objetivos e questões de pesquisa, os professores escolhem, desenvolvem e aplicam abordagens que tornem visíveis a aprendizagem dos estudantes, verificando como os alunos aprendem e refletindo sobre a aprendizagem com base nas observações da aula planejada. Essa análise pode originar a reformulação do plano da aula, alterando a estratégia seguida, os materiais a serem usados, as tarefas que serão propostas ou, ainda, as questões que serão elaboradas para os alunos (Baptista et al., 2014).

Observa-se então que a metodologia de EA tem como centro da atenção a aprendizagem dos alunos. Pedder (2014) comenta que o Estudo de Aula estabelece a aprendizagem como um foco explícito e visível das discussões dos professores. Os professores, através dos encontros de planejamento e avaliação, podem se tornar mais conscientes de como e porque a aprendizagem ocorre, visando melhorar o caminho para auxiliar seus estudantes no aprendizado.

O EA é majoritariamente aplicado na área de educação matemática, mas, aos poucos tem sido inserido na área de ciências naturais (Física e Química). No Brasil, isto não é diferente. Em um levantamento realizado acerca de produções científicas nacionais sobre o EA, foi verificado que a maior parte destes eram originados de teses e dissertações. Bonotto, Gioveli e Scheller (2019), autoras do levantamento, listaram 10 trabalhos acadêmicos (9 dissertações e 1 tese) defendidas entre 2010 e 2018, sendo 9 da área de Matemática e 1 de Letras-Inglês. Este fato denota a relevância desta pesquisa, pois, além de trabalhar com tópicos de Física, ainda mescla a formação continuada de professores em serviço com a formação inicial de licenciandos em Física. Mais à frente delinearemos melhor como isto ocorreu.

Por necessitar de constante contato entre os professores, os quais ocorrem em encontros de planejamento e avaliação de aulas, os encontros de EA podem ser potencializados pela formação de uma Comunidade de Prática. 


\section{Comunidades de Prática}

Uma Comunidade de Prática $(\mathrm{CP})$ se forma quando um grupo de pessoas se une para desenvolver maneiras compartilhadas de buscar interesses comuns. Essas maneiras compartilhadas envolvem a prática de determinada ação e resulta na aprendizagem (Lave \& Wenger, 1991). Segundo a proposta destes autores, uma CP seria um núcleo em que as interações entre os sujeitos produziriam conhecimentos e gerariam o desenvolvimento sócio-cognitivo. O conceito de Comunidades de Prática surgiu com a Teoria Social da Aprendizagem, de Etienne Wenger. A Teoria Social da Aprendizagem enfatiza a perspectiva da aprendizagem no contexto da experiência de participação na sociedade (Santos \& Arroio, 2015).

De acordo com Wenger (2008), uma CP pode ser formada por indivíduos que desenvolvem maneiras compartilhadas de buscar interesses comuns, sendo que a participação destes indivíduos pode ocorrer de forma central, essencial (ativo), ou de forma periférica, com menos representatividade. O participante central ocupa o posto de líder da comunidade, com o papel de conduzir os projetos, propor novos temas e desafios. Os participantes ativos são aqueles que se encontram regularmente e participam de forma efetiva nas discussões, expondo suas impressões e colaborando com as discussões e construções coletivas. Já os participantes que estão no nível periférico, por sua vez, vão observando, aprendendo e, à medida que se inteiram sobre as atividades e práticas da comunidade, passam a ser aceitos como membros e a atuar mais ativamente na comunidade (Lave \& Wenger, 1991).

A participação periférica ocorre por causa das múltiplas formas possíveis de engajamento dos membros na Comunidade de Prática e envolve o desenvolvimento de uma identidade dentro da comunidade à medida em que os membros apresentam maior engajamento. No entanto, não há um lugar fixo onde os membros da Comunidade de Prática ficam alocados. Lave e Wenger (1991) enfatizam que a participação periférica sugere uma abertura, um modo de obter acesso a fontes para entendimento da prática por meio de um envolvimento crescente com os membros da Comunidade de Prática. As formas de participação podem ser visualizadas por meio da Figura 1.

O conceito de CP definido por Wenger (2008) pode ser caracterizado por meio de três dimensões inter-relacionadas: engajamento mútuo, empreendimento conjunto e um repertório compartilhado. $\mathrm{O}$ engajamento mútuo representa a interação entre indivíduos que leva à criação de significado compartilhado acerca de questões ou de um problema. Empreendimento conjunto é o processo em que as pessoas estão envolvidas e trabalhando juntas em direção a um objetivo comum. Por fim, o repertório compartilhado refere-se aos recursos e jargões comuns que os membros usam para negociar significado e facilitar a aprendizagem dentro do grupo.

Convém salientar que uma Comunidade de Prática se forma espontaneamente, mas sua formação pode ser induzida ao se colocar um grupo atuando em prol de um objetivo em comum. Nem todo agrupamento de pessoas é uma Comunidade de Prática. Para isto é necessário que ocorram as três dimensões descritas por Wenger. Assim, um 
grupo pode ser induzido a trabalhar conjuntamente em prol de um objetivo comum, mas não se engajar e não apresentar repertório compartilhado, levando a não caracterização da Comunidade de Prática.

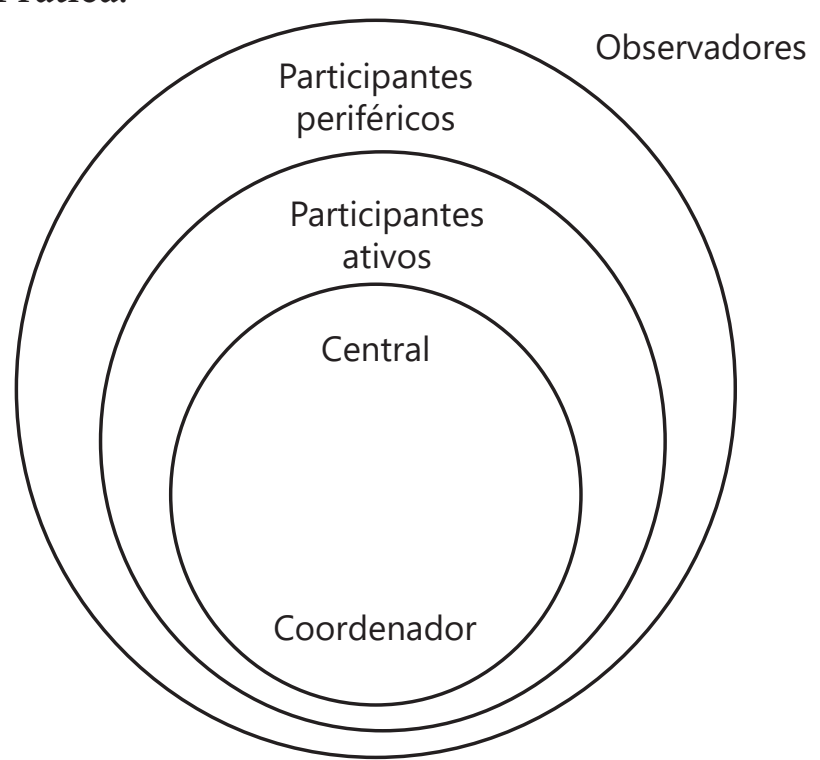

Figura 1. Representação gráfica dos níveis de participantes numa CP, baseada em Lave e Wenger (1991)

A partir das características que definem a Comunidade de Prática, Wenger (2008) propõe alguns possíveis indicadores de que uma Comunidade de Prática se formou, conforme podemos visualizar na Figura 2. Estes indicadores estão relacionados e são derivados das três características da formação de uma Comunidade de Prática discutidas anteriormente: engajamento mútuo, projeto em conjunto e repertório compartilhado.

\begin{tabular}{|l|}
\hline Indicador de Wenger \\
\hline 1. Relações mútuas sustentadas - harmoniosas ou conflituosas \\
\hline 2. Maneiras compartilhadas de se envolver em fazer as coisas juntos \\
\hline 3. O rápido fluxo de informação e propagação da inovação \\
\hline $\begin{array}{l}\text { 4. Ausência de preâmbulos introdutórios, como se conversas e interações fossem meramente a } \\
\text { continuação de um processo em andamento }\end{array}$ \\
\hline 5. Configuração muito rápida de um problema a ser discutido \\
\hline 6. Substancial sobreposição nas descrições dos participantes sobre quem pertence \\
\hline 7. Saber o que os outros sabem, o que podem fazer e como podem contribuir com o grupo \\
\hline 8. Identidades definidas mutuamente \\
\hline 9. Capacidade de avaliar a adequação de ações e produtos \\
\hline 10. Ferramentas específicas, representações e outros artefatos \\
\hline 11. Conhecimento local, histórias compartilhadas, piadas internas, riso conhecido \\
\hline 12. Jargão e atalhos para comunicação, bem como a facilidade para produzir novos \\
\hline 13. Certos estilos reconhecidos como exibição da membresia do grupo \\
\hline 14. Discurso compartilhado refletindo uma certa perspectiva do mundo \\
\hline
\end{tabular}

Figura 2. Indicadores de Wenger para a presença de comunidade de prática

Fonte: Wenger (2008, p. 125 - tradução nossa). 
O autor destaca que os indicadores se apresentam como balizas para a identificação da formação de uma Comunidade de Prática, não sendo necessário a apresentação de todos eles, nem por todos os participantes, para caracterizar a formação da mesma. Comunidades de Prática, nesse sentido, não podem ser reduzidas a propósitos puramente instrumentais. Elas estão relacionadas ao conhecimento, mas também ao convívio social, aos significados que essas relações trazem, a desenvolver identidades e, acima de tudo, ao ser humano (Wenger, 2008).

Conforme sugerido por Wenger (2008) as atividades desenvolvidas em CP promovem a aprendizagem em projetos compartilhados por seus membros. Assim, podemos dizer também que a formação de uma Comunidade de Prática pode promover o desenvolvimento profissional das pessoas envolvidas neste processo.

Sendo assim, o objetivo deste trabalho é apresentar uma investigação com base no estudo de caso de formação de duas Comunidades de Prática nas quais ocorreu uma adaptação do Estudo de Aula ao ensino de Física no contexto brasileiro. Deste modo, pretende-se analisar se e como Comunidades de Prática foram constituídas em reuniões de formação inicial e continuada de professores da cidade de Teresina no estado do Piauí durante a realização de ciclos de Estudo de Aula.

\section{Metodologia}

O presente trabalho se desenvolveu a partir da observação da formação de duas Comunidades de Prática nas quais se encontravam periodicamente professores de Física em exercício e estudantes do curso de licenciatura em Física. Nestes dois grupos, ocorreram encontros de ciclos formativos de Estudo de Aula, de forma a discutir sobre a questão norteadora proposta: como fazer para contextualizar o ensino de Física e despertar o interesse dos alunos pela matéria? Abordando o conteúdo que seria ministrado pelo professor voluntário, de acordo com o seu próprio planejamento, desenvolvemos a aula de investigação, nome dado à aula produzida coletivamente nos encontros formativos.

Como o EA é uma metodologia ainda pouco conhecida e utilizada no Brasil, ocorreram dois estudos pilotos, sendo um com licenciandos em Física e outro com professores de Física da educação básica, de modo a efetuar uma adequação do método à realidade local, testar a metodologia a ser aplicada junto aos professores (o que ocorreu no $2^{\circ}$ piloto) e o refino da técnica. Como resultado destes dois estudos pilotos, foi constatado que seria interessante e inovador propor o EA mesclando professores em serviço e licenciandos.

Daí emergiu a utilização de Comunidades de Prática, pois, em nossa proposta, não seria o Pesquisador o único responsável por expor as possibilidades de atuação nas aulas que seriam produzidas coletivamente. Este fato difere do EA clássico, pois neste a aula ministrada pelo professor experiente no EA é reproduzida pelos demais. $\mathrm{Na}$ abordagem que utilizamos em nossa pesquisa, os participantes, quer fossem docentes ou licenciandos, poderiam ter voz ativa e sugerir ou propor algo, especialmente os 
professores que ministrariam as aulas planejadas coletivamente, pois estes conheciam bem as suas turmas. O contato entre professores em serviço e futuros professores nesta discussão poderia gerar o desenvolvimento profissional para ambos.

A proposta de atividades de Estudo de Aula que resultou nesta pesquisa uniu professores e licenciandos. Foram criados dois grupos distintos: o Grupo 1 (G1), composto pelo Pesquisador (primeiro autor deste trabalho), três docentes de Física de duas escolas públicas do Estado do Piauí (Pedro, José e Moisés) ${ }^{1}$ e quatro licenciandos em Física da Universidade Federal do Piauí (UFPI) (Mateus, Lucas, Isaque e Eliseu); e o Grupo 2 (G2), composto pelo Pesquisador, seis professores de Física da educação básica (Davi, Silas, Tiago, João, Paulo e Timóteo), todos mestrandos do Mestrado Nacional Profissional em Ensino de Física da UFPI (MNPEF) e cinco licenciandos em Física da UFPI (Rebeca, Felipe, Marcos, César e Sara). Os encontros ocorreram ao longo do ano de 2018.

Convém salientar que os grupos supracitados no início das atividades não poderiam ser classificados como Comunidades de Prática, pois ainda não apresentavam características que viriam a ser desenvolvidas ao longo dos encontros formativos. Os ciclos formativos ocorreram da seguinte forma: 1) primeiro encontro com definição do conteúdo que seria trabalhado no ciclo e do professor ou licenciando que iria ministrar a aula de investigação ${ }^{2}$; estudo do conteúdo visando aprofundar o conhecimento dos docentes sobre um tópico específico em Física, bem como elaboração coletiva da aula e definição dos itens que seriam observados nesta; 2 ) segundo encontro com ministração e observação da aula de investigação e 3 ) terceiro encontro com reflexão sobre a aula observada e sobre todo o processo do Estudo de Aula. Se os participantes julgassem necessário, a aula analisada poderia ser revista e novamente aplicada, porém por outro professor e em outra turma, e posteriormente discutida coletivamente.

As Figuras 3 e 4 apresentam a sequência de encontros e ciclos formativos que ocorreram em cada grupo.

Podemos perceber, com base nas figuras 3 e 4 , que em alguns encontros (encontro 5, no G1 e encontros 4 e 6, no G2) ocorreram mais de uma etapa, sendo a terceira etapa de um ciclo e a primeira etapa do outro. Isto ocorreu porque o tempo disponibilizado para os encontros era mínimo, pois todos os docentes de ambos os grupos possuíam responsabilidades referentes a mais de uma ocupação, quer como professores ou não.

1 Os nomes dos integrantes foram modificados para preservar as suas identidades. Dois professores, sendo um de cada grupo (Moisés e Silas), e um dos licenciandos (Eliseu) do G1 só participaram do $1^{\circ}$ encontro do primeiro ciclo formativo de seu respectivo grupo.

2 A definição do tema e do professor ministrante deste tema, conforme proposta ocorrida nos encontros, poderia ocorrer também via aplicativo de mensagens instantâneas (WhatsApp), visto que todos os integrantes dos dois grupos estavam inseridos em grupos criados com a finalidade de facilitar o contato entre o pesquisador e os integrantes e também entre os próprios integrantes dos grupos. 


\begin{tabular}{|c|c|l|}
\hline Encontro & Ciclo & Atividade \\
\hline 1 & 1 & $\begin{array}{l}\text { Encontro para estudo, planejamento da aula de investigação e definição dos } \\
\text { itens a serem observados e do voluntário para lecionar a mesma }\end{array}$ \\
\hline 2 & 2 & $\begin{array}{l}\text { Encontro para estudo, planejamento da aula de investigação e definição dos } \\
\text { itens a serem observados e do voluntário para lecionar a mesma }\end{array}$ \\
\hline 3 & 1 & Ministração da aula de investigação \\
\hline 4 & 2 & Ministração da aula de investigação \\
\hline 5 & 1 e 2 & $\begin{array}{l}\text { Encontro para discussão sobre as aulas de investigação e definição do } \\
\text { voluntário para ministrar a aula e conteúdo a ser estudado no próximo ciclo }\end{array}$ \\
\hline 6 & 3 & $\begin{array}{l}\text { Encontro para estudo, planejamento da aula de investigação e definição dos } \\
\text { itens a serem observados }\end{array}$ \\
\hline 7 & 3 & Encontro para a avaliação das atividades de EA \\
\hline
\end{tabular}

Figura 3. Encontros formativos de EA para o G1

Fonte: os autores.

\begin{tabular}{|c|c|c|}
\hline Encontro & Ciclo & Atividade \\
\hline 1 & 1 & $\begin{array}{l}\text { Encontro para falar acerca do método de Estudo de Aula e das atividades } \\
\text { previstas para os encontros e definição do voluntário para o primeiro ciclo }\end{array}$ \\
\hline 2 & 1 & $\begin{array}{l}\text { Encontro para estudo, planejamento da aula de investigação e definição dos } \\
\text { itens a serem observados }\end{array}$ \\
\hline 3 & 1 & Ministração da aula de investigação \\
\hline 4 & 1 e 2 & $\begin{array}{l}\text { Encontro para discussão da aula de investigação (ciclo 1) e definição do } \\
\text { voluntário para ministrar a aula e conteúdo a ser estudado no próximo ciclo, } \\
\text { bem como estudo, planejamento da aula de investigação e definição dos itens } \\
\text { a serem observados (ciclo 2) }\end{array}$ \\
\hline 5 & 2 & Ministração da aula de investigação \\
\hline 6 & 2 e 3 & $\begin{array}{l}\text { Encontro para discussão da aula de investigação (ciclo } 2 \text { ) e definição do } \\
\text { voluntário para ministrar a aula e conteúdo a ser estudado no próximo ciclo, } \\
\text { bem como estudo, planejamento da aula de investigação e definição dos itens } \\
\text { a serem observados (ciclo 3) }\end{array}$ \\
\hline 7 & 3 & Ministração da aula de investigação \\
\hline 8 & 3 & $\begin{array}{l}\text { Encontro para discussão da aula de investigação e para a avaliação das } \\
\text { atividades de EA }\end{array}$ \\
\hline 9 & - & Encontro para a avaliação das atividades de EA (licenciandos) \\
\hline
\end{tabular}

Figura 4. Encontros formativos de EA para o G2

Fonte: os autores.

Os encontros formativos foram gravados em áudio e vídeo e posteriormente transcritos. Optamos por gravação em áudio e vídeo para que pudéssemos registrar, na íntegra, tudo o que fora falado e discutido nos encontros formativos, bem como identificar os autores das falas e as suas respectivas (re)ações. Já os encontros em que ocorreram a ministração das aulas de investigação, os quais ocorreram nas escolas de lotação dos docentes participantes das formações, foram registrados de forma diferente. 
As equipes gestoras de todas as escolas não permitiram a gravação das aulas em áudio e vídeo, para, segundo elas, preservar a imagem dos alunos e das escolas. Estes encontros contaram com a presença, além do professor ministrante, de, no mínimo, um ou dois docentes ou licenciandos. As observações acerca destes encontros se deram por meio de anotações em diário de campo e das falas proferidas no encontro para discussão pelo professor ministrante e/ou pelos observadores. Este encontro foi gravado em áudio e vídeo.

Foi em cima destas transcrições que ocorreu a análise do corpus, usando para isto a análise de conteúdo de Bardin (2016). O processo de análise de dados em si envolve várias etapas para auferir significação aos dados coletados, as quais são organizadas por Bardin em três fases: 1) pré-análise, 2) exploração do material e 3) tratamento dos resultados, inferência e interpretação.

A pré-análise é o momento em que o material a ser analisado é organizado com o objetivo de torná-lo operacional, sistematizando as ideias iniciais. Esta organização ocorre através de quatro etapas: leitura flutuante; escolha dos documentos; formulação das hipóteses e dos objetivos; e referenciação dos índices e elaboração de indicadores (Bardin, 2016). Nesta etapa, ficou definido que seriam utilizados os indicadores de Wenger para a presença de CP, para investigar se os grupos formativos se tornariam Comunidades de Prática.

A segunda fase, exploração do material, consiste na definição de categorias e a identificação das unidades de registro e das unidades de contexto nos documentos. Para Bardin (2016), esta etapa é importante pois vai possibilitar ou não a riqueza das interpretações e inferências. Nela, ocorre a descrição analítica, a qual diz respeito ao corpus (qualquer material textual coletado) submetido a um estudo aprofundado, orientado pelas hipóteses e referenciais teóricos. Dessa forma, a codificação, a classificação e a categorização são básicas nesta fase. Nesse momento, as transcrições dos encontros foram lidas cuidadosamente e as falas que demonstrassem os indicadores de Wenger foram identificadas, tornando-se nossas categorias de análise.

A terceira e última fase é destinada ao tratamento dos resultados, por meio da inferência e interpretação. Nesta etapa, ocorre a condensação e o destaque das informações para análise. Como produto final desta etapa (e do processo), temos as interpretações inferenciais. Esta fase é o momento da intuição, da análise reflexiva e crítica (Bardin, 2016). Foi nesta etapa que refletimos sobre o papel dos integrantes dentro das CP, bem como a movimentação destes nelas. Refletimos, também, acerca da relação entre o EA e a CP e a viabilidade da utilização desta metodologia no contexto local.

Para facilitar a compreensão, os encontros foram nomeados de acordo com a ordem em que ocorreram em cada ciclo. Ex: o $2^{\circ}$ encontro do $3^{\circ}$ ciclo do G2 foi nomeado E2 C3 G2. Na seção seguinte, apresentaremos os resultados desta investigação. 


\section{Resultados e discussão}

A partir da formação dos dois grupos (G1 e G2), foi possível observar o papel dos participantes e como a atuação destes pode contribuir no desenvolvimento profissional deles enquanto professores e futuros professores de Física. Em relação ao EA, tal como fora falado na metodologia, fizemos ciclos formativos de três encontros, cada. Tendo em vista a dificuldade em todos os participantes reunirem-se para as atividades, normalmente o encontro que encerrava um ciclo formativo iniciava um novo.

Durante os encontros nos dois grupos ${ }^{3}$ foi possível perceber que o envolvimento dos participantes com o grupo e com suas atividades foi mudando ao longo do tempo. Em cada um dos grupos havia o Pesquisador, que fazia o papel central, segundo Lave e Wenger (1991), no qual atua como líder e propõe as atividades a serem desenvolvidas pelo grupo nos seus encontros. Os demais integrantes, professores de Física em serviço e os licenciandos em Física, assumiram posições de membros ativos e periféricos, respectivamente. Não ficou determinado, a priori, o nível de participação destes atores, se ativo ou periférico. A proposta seria que essa determinação do grau de participação ocorresse naturalmente durante os encontros.

Desde o princípio, os professores assumiram o papel de membros ativos nos grupos. A participação destes se deu de forma bem mais efetiva que a dos licenciandos. A participação dos licenciandos ocorreu de forma diferente nos dois grupos. No Grupo 1 (G1), os licenciandos participaram mais ativamente, especialmente no decorrer dos encontros. No Grupo 2 (G2), a participação destes não chegou a ser ativa em nenhum dos encontros. As Tabelas 1 e 2 elencam as quantidades de falas por encontro, por participante, e nos apresentam informações relevantes para compreendermos um pouco mais acerca da participação dos diversos integrantes de cada um dos grupos.

Tabela 1. Quantitativo de falas por encontro, por participante do G1

\begin{tabular}{lccccccc}
\hline & Status & E1 C1 & E1 C2 & E3 C1 C2 & E1 C3 & E2 C3 & Total \\
\hline Pesquisador & $\mathrm{F}$ & 191 & 202 & 26 & 115 & 79 & 613 \\
\hline Moisés & $\mathrm{P}$ & 33 & - & - & - & - & 33 \\
\hline José & $\mathrm{P}$ & 165 & 122 & 17 & 77 & 53 & 434 \\
\hline Pedro & $\mathrm{P}$ & - & 64 & 8 & - & 19 & 91 \\
\hline Lucas & $\mathrm{L}$ & 2 & 8 & - & 18 & 5 & 33 \\
\hline Eliseu & $\mathrm{L}$ & 19 & - & - & - & - & 19 \\
\hline Mateus & $\mathrm{L}$ & - & 9 & - & 34 & - & 43 \\
\hline Isaque & $\mathrm{L}$ & - & 20 & 1 & - & 8 & 29 \\
\hline Total & & 410 & 425 & 52 & 244 & 164 & 1295 \\
\hline
\end{tabular}

Legenda: F - formador, P - professor, L - licenciando; E1 - Encontro 1, E2 - Encontro 2; C1 - Ciclo 1; C2 Ciclo 2, C3 - Ciclo 3.

Fonte: os autores.

3 Escolhemos denominar de grupos e não de Comunidades de Prática, pois nos primeiros encontros, por definição, não poderíamos afirmar que eram Comunidades de Prática. 
Tabela 2. Quantitativo de falas por encontro, por participante do G2

\begin{tabular}{lcccccccc}
\hline & Status & E1 C1 & E2 C1 & $\begin{array}{c}\text { E4 C1 / } \\
\text { E1 C2 }\end{array}$ & $\begin{array}{c}\text { E3 C2 / } \\
\text { E1 C3 }\end{array}$ & E3 C3 & $\begin{array}{c}\text { Av. } \\
\text { Licenc. }\end{array}$ & Total \\
\hline Pesquisador & $\mathrm{F}$ & 56 & 130 & 141 & 170 & 97 & 44 & 638 \\
\hline Davi & $\mathrm{P}$ & 9 & 55 & 31 & 35 & 18 & - & 148 \\
\hline Paulo & $\mathrm{P}$ & 37 & 92 & 158 & 72 & 68 & - & 427 \\
\hline Tiago & $\mathrm{P}$ & 6 & 27 & 28 & 66 & 38 & - & 165 \\
\hline João & $\mathrm{P}$ & 4 & 17 & - & 66 & - & - & 87 \\
\hline Miguel & $\mathrm{P}$ & 5 & - & - & - & - & - & 5 \\
\hline Timóteo & $\mathrm{P}$ & - & 11 & 29 & - & - & - & 40 \\
\hline Felipe & $\mathrm{L}$ & 2 & - & 4 & - & - & 11 & 17 \\
\hline Sara & $\mathrm{L}$ & 0 & 3 & 0 & - & - & 13 & 16 \\
\hline Rebeca & $\mathrm{L}$ & 0 & - & 2 & - & - & 14 & 16 \\
\hline César & $\mathrm{L}$ & 1 & - & 0 & - & - & 9 & 10 \\
\hline Augusto & $\mathrm{L}$ & 0 & - & - & 4 & - & 2 & 6 \\
\hline Total & & 120 & 335 & 393 & 413 & 221 & 93 & 1575 \\
\hline
\end{tabular}

Legenda: F - formador, P - professor, L - licenciando; E1 - Encontro 1, E2 - Encontro 2, E3 - Encontro 3; E4 Encontro 4; C1 - Ciclo 1; C2 - Ciclo 2, C3 - Ciclo 3.

Fonte: os autores.

Nas Tabelas 1 e 2, a coluna status indica qual era a posição do participante no curso: F significa formador; P, professor; e L é licenciando. Vale ressaltar que dentre as formas de avaliar a participação, as falas foram a forma escolhida, pois representavam bem o envolvimento no grupo, uma vez que os participantes mais ativos em outros aspectos, tais como na disponibilidade para participar dos encontros, na participação no grupo de mensagens instantâneas (WhatsApp) etc., eram os que falavam mais e os menos ativos também não participavam com suas falas.

Nos encontros em que as aulas foram planejadas, o professor que iria lecionar tais aulas participou mais que nos demais encontros. Podemos verificar isto em relação às falas dos professores José no E1 C1 e Pedro no E1 C2, no G1 (Tabela 1) e Davi no E2 C1, Paulo no E3 C1/E1 C2 e João no E3 C2/E1 C3, no G2 (Tabela 2). Em todos os encontros, nos dois grupos, a participação dos professores foi efetiva. A presença deles também.

Convém ressaltar que no EA tradicional existe um profissional experiente que direciona as atividades e mostra como deve ser a aula de investigação. Este formato não é muito flexível. O profissional experiente conduz as atividades e os demais participantes buscam se apropriar do método para, posteriormente, serem multiplicadores e poderem conduzir o seu próprio grupo. Um conteúdo, como por exemplo, frações, é estudado e, a partir disto, surge o problema de pesquisa, tal como: "como fazer o aluno compreender que a fração $2 / 4$ é equivalente a 3/6 e 1/2?". Esta questão vai permear todos os encontros formativos do grupo em questão. 
Quando propusemos o EA em uma perspectiva de CP, isto foi modificado: não seria uma aula pronta, planejada por um professor com grande experiência em EA, que seria imitada; as aulas foram planejadas coletivamente de acordo com o planejamento e forma de trabalhar do professor voluntário, visto que o planejamento deste é rígido. Essa rigidez no planejamento ocorre, pois em todas as redes de ensino (particular, pública ou filantrópica) em que os docentes investigados trabalham existem simulados da rede que são aplicados regularmente, o que permite pouca alteração no planejamento para que os alunos não sejam prejudicados.

No EA tradicional, a movimentação da função dos integrantes dos grupos formativos ocorre de forma mais estática que na proposta aqui descrita e, muitas vezes, esta movimentação não ocorre, o que não caracteriza uma CP. A questão de pesquisa foi: "Como aproximar os conteúdos de Física da realidade do aluno e aumentar o interesse dele por esta disciplina? ". Esta questão era utilizada em quaisquer conteúdos de Física que o professor estivesse lecionando. Com isto, a interação dos professores e licenciandos foi maior. Ademais, foi perceptível a migração dos professores em direção ao papel central. $\mathrm{O}$ profissional que conduzia o processo tinha um papel mais de um facilitador, pois incentivava a participação e discussão entre os pares e não apresentava um produto finalizado. Esta foi a principal diferença ao propormos o EA como uma CP, sendo, pois, uma abordagem que não fora utilizada anteriormente em trabalho com o EA.

Em relação aos licenciandos, conforme dito acima, no G1, a participação se deu de forma mais ativa. Convém salientar que os licenciandos que participaram do G1 já tinham experiência como docente, enquanto os do G2 não, bem como estavam mais próximos da conclusão do curso que estes. Este fator levou a uma maior participação nas atividades de Estudo de Aula, pois estes licenciandos já haviam exercido o papel de professor em escolas e poderiam participar das discussões expondo as suas próprias experiências.

Os dados apresentados mostram alguns indícios acerca da participação dos professores e dos licenciandos nos grupos e nos revelam um pouco acerca da formação das CP e dos papéis desempenhados pelos seus integrantes nos grupos. Com base nos indicadores de formação de Comunidade de Prática (Wenger, 2008), é possível refletir acerca da formação destas.

Para investigarmos se ocorreu a formação de CP nos grupos 1 e 2 (G1 e G2), usamos como base a proposta de indicadores de presença de Comunidade de Prática, de Wenger (2008). Nesta proposta, o autor apresenta 14 indicadores que, segundo ele, indicam que ocorreu a formação de CP. Durante a pesquisa, verificamos a presença de alguns indicadores de formação da CP. Visando expor a presença destes indicadores, utilizaremos alguns excertos que consideramos bem representativos, segundo a nossa compreensão, os quais podem ser do G1 e/ou G2. Optamos por citar exemplos de ambos os grupos, pois as discussões e interações ocorriam de forma semelhante nos dois, com diferença na postura dos licenciandos nestes. Sobre isto, falaremos mais detalhadamente ao final desta seção. 
O primeiro indicador verificado foi "Relações mútuas sustentadas - harmoniosas ou conflituosas". Este indicador ficou evidenciado ao longo dos encontros, pois houve um bom ambiente durante as atividades realizadas. Este ambiente mostrou-se bem harmônico. Não houve discussões nem estranhamentos entre os participantes, mas compartilhamento de informações, conforme podemos verificar nos excertos a seguir.

- Então, os três processos: condução, convecção e irradiação. Condução. Quando eu falo de condução, eu imagino logo o transporte público, que é a condução que eu pego para chegar a tal ponto. Tem a ver com este conceito? (Pesquisador)

(silêncio)

— Tem! Porque há o deslocamento... (Pesquisador)

- Deslocamento de energia. Eu tenho medo deles [os alunos] se confundirem com o deslocamento das moléculas, deste teu exemplo aí. (José)

(linhas 179-185 E1 C1 G1)

— O principal é força elétrica! Sem isto, você não vai conseguir definir campo [elétrico]. (Tiago)

— Pois é! Eu faço uma abordagem mais diferente! (Paulo)

- Por vetor! (João)

— Isto! Primeiro a questão da [inaudível]. Eu uso uma ferramenta, que o pessoal utiliza em física, a tempestade mental. Nós enchemos o aluno de pergunta, bombardeando mesmo de pergunta, até eles ficarem na angústia pela resposta, mas nós não damos a resposta. A gente pode colocar a questão: o que eles pensam de campo? Aí, tem a questão do campo de futebol e eles vão exaurindo, exaurindo, vão falando. (Paulo)

- Uma maiêutica? Mais ou menos parecido com aquela técnica de Sócrates, do cara ir respondendo e você vai perguntando de modo a guiar a resposta dele. (Pesquisador)

(linhas 20-29 E2 C1 G2)

Assim, podemos constatar alguns exemplos que demonstram a convivência harmoniosa, mesmo com discordâncias. Também ocorreram falas com apresentação da própria experiência docente. A convivência harmoniosa ocorreu ao longo de todos os encontros. Os licenciandos também expuseram o seu ponto de vista e compartilharam as suas experiências, como podemos verificar no excerto a seguir:

- A turma era grande. Mas, aí tem aquela questão: uma boa parte estava tentando, se esforçando. E tinha aquela parte que também não quer: tinha uns que estavam com a cabeça baixa, lá no canto... E o professor, também, não chegou a perder uma quantidade de tempo pedindo pra eles prestarem atenção. Então, ele focou naqueles que realmente estavam prestando atenção. Teve a questão de aluno chegando atrasado. Com 15 minutos de aula, ainda tinha alunos chegando na sala. Teve um momento que em ele 
[o professor] colocou uma cadeira atrás da porta [para fechar a mesma]. Aí, um aluno chegou já chutando a porta. (Mateus)

—É por isso que você vê que o planejamento da aula... (Lucas)

— Pois é! (Pesquisador)

— Eu fico pensando: se uma aula que a gente planejou, às vezes, não dá certo. Imagina se você chegar sem planejar! (Lucas)

(linhas 73-83 E1 C3 G1)

Conforme já dito, os licenciandos do G1 tiveram um papel ativo, compartilhando o conhecimento e as experiências, numa relação mais equitativa com os professores. A participação dos licenciandos do G2 se dava basicamente quando eram questionados nominalmente pelo Pesquisador. Embora o envolvimento destes tenha sido menos constante, a presença deles era incentivada e o ambiente dos encontros era harmônico. Quando comparamos com o G1, os licenciandos do G2 tiveram um papel extremamente passivo.

O segundo indicador verificado foi "Maneiras compartilhadas de se envolver em fazer as coisas juntos". Este indicador pode ser verificado nas falas dos participantes dos dois grupos comentadas acima. Os participantes se envolviam, participavam das atividades e expunham a própria prática. Isto pode ser verificado em todos os encontros. Este envolvimento, tal como no G1, era mais evidenciado, especialmente, no momento de estudo do conteúdo da aula de investigação, mas também, em menor intensidade, na elaboração do plano de aula desta.

Os participantes, de forma geral, se envolveram nas atividades durante o estudo do conteúdo. Os licenciandos do G1 também se envolveram por vontade própria, participando da discussão entre os pares, conforme podemos verificar nos trechos abaixo:

- Na cinemática a referência é a distância entre os pontos. Vemos se a distância aumentou ou diminuiu. A gente vê se a distância aumenta ou diminui com o passar do tempo ou ainda se esta distância permanece a mesma. (José)

- Se ela [a distância] está diminuindo, então há o movimento. Se ela aumenta, também. (Pesquisador)

- Se ela [a distância] muda, então há um movimento. Se a distância muda com o tempo, então, há movimento. Se esta distância não muda com o tempo, então não há um movimento, há um repouso. (Pedro)

- Unrum. (Pesquisador)

- a gente escolhe um ponto, que é o ponto inicial, para comparar se a distância a este ponto aumenta ou diminui com o passar do tempo. (Pedro) 
-É o ponto de partida, no caso. (Isaque)

— o objeto está parado ou em movimento, em relação a que? (Pesquisador)

- Um carro, por exemplo, sai da sua casa e retorna à sua casa, está em movimento? Para você, que está dentro, está em repouso. (José)

- Pois é. (Pesquisador)

- Então, também deixar claro para o aluno isto: que algo pode estar em repouso e em movimento, ao mesmo tempo... (José)

— Dependendo do referencial! (Mateus)

- Certo! Então, neste primeiro momento, não precisa falar nada de referencial inercial, coisa assim, não! Deixa para depois!(Pesquisador)

(linhas 95-115 E1 C2 G1)

- Você colocaria [este experimento] neste momento, agora? Esse experimento de Oersted, você colocaria nesta aula? (Pesquisador)

- Não agora. Essa parte do experimento é quando a gente vai falar de motor, né? Motor elétrico, que é aquela relação como funciona... (Paulo)

- Em nenhum momento tu fala de corrente elétrica. (Timóteo)

- Sim. (Paulo)

— Tem que falar! (Timóteo)

— Na multidão dos conselhos, tem-se a sabedoria! (Pesquisador)

— Ia falar disso quando fosse falar de motor, de motor elétrico. (Paulo)

- Tiago - Tu falas de espira? (Tiago)

- Sim. (Paulo)

- Sem [falar de] corrente? (Tiago e Timóteo)

- Não. É uma coisa que já foi dada! Olha, quando a gente fala no conceito de campo elétrico ou de campo magnético... O que é o campo magnético? É uma alteração produzida no espaço devido ao movimento das cargas. Então, o conceito de campo magnético, aborda... já insere a corrente elétrica. É impossível você falar de campo magnético sem [falar de] a corrente elétrica. (Paulo)

- Não existe campo magnético sem isso daí. (Pesquisador) 
- Essa parte da experiência do cara, eu falo depois! (Paulo)

— Fala de bússola, fala do fio... Tu fala de tudo isso? (Timóteo)

(linhas 548-567 E3 C1/E1 C2 G2)

Os excertos anteriores demonstram o envolvimento dos participantes com os colegas no compartilhamento de conhecimentos acerca dos assuntos que eram estudados nos encontros. O indicador em questão também foi verificado na elaboração do plano de aula, como podemos verificar a seguir:

- A gente vai fazer assim, fontes, classificação e etc. Tá bom demais! Metodologia ... [escrevendo no quadro](Pesquisador)

- Definiria como? (Davi)

- Definiria o que? (Pesquisador)

- O tipo de aula: expositiva, mesmo? (Davi)

- Vou dizer assim: vai começar sendo introduzida com um vídeo que ele vai postar [no whatsapp] antes da aula. A aula dele vai começar antes da aula! (Pesquisador)

- A tua aula vai começar com o vídeo? [falando com Paulo] (Timóteo)

- É porque no vídeo vai ter a problematização e esse daí vai ser o elemento motivador. (Pesquisador)

- Dez minutos fazendo uma série de perguntas: o que é esse movimento? Por que esse movimento está serpenteando? Por que que o fio tem que estar grudado, preso? (Paulo)

- Vou colocar aqui [escreve no quadro]: a aula será introduzida com exibição de um vídeo mostrando... (Pesquisador)

- O efeito da força magnética no fio. (Paulo)

(linhas 655-669 E4 C1/E1 C2 G2)

Percebemos, com base no exposto no trecho acima, que mesmo sendo uma aula planejada para ser lecionada por um professor - no caso do trecho acima era pelo professor Paulo - os colegas participavam, sugeriam e questionavam, também, demonstrando envolvimento com a atividade.

Outro indicador proposto por Wenger (2008) verificado na análise foi "Rápido fluxo da informação e propagação da inovação". Foi constatado este indicador especialmente quando os participantes compartilhavam as suas experiências ou quando estavam comentando sobre as aulas de investigação que haviam sido lecionadas. Todo o Encontro 3 dos ciclos 1 e 2 do G1, basicamente, pode ser considerado uma amostra deste indicador, visto que ocorre um comentário acerca das duas primeiras aulas de 
investigação planejadas no G1. Como exemplo de compartilhamento de experiências, podemos destacar o seguinte trecho, recuperado do E3 C2 / E1 C3 do Grupo 2:

- É mais eu comecei agora na SEDUC [Secretaria de Educação e Cultura do Estado do Piauí]. Lá, é um projeto novo: dou aula na associação dos cegos. (Tiago)

\section{$[\ldots]$.}

— E aí, na Associação dos Cegos, você realmente não pode ficar preso na questão de cálculo. Tem que tentar... (Pesquisador)

— Eu estou usando um projeto da Universidade Estadual da Bahia chamado Física no Cotidiano. São vídeos, que eles explicam tão bem, contextualiza tão bem, que ele faz a física no cotidiano, é uma situação no cotidiano, que aí vai acontecendo. Eu tenho todo o programa aqui. Não me atentei quem é o responsável. Sei que é financiado pelo FNDE e eu levo para casa os vídeos. (Tiago)

\section{$[\ldots]$}

- Aí eles escutam o áudio, que fala sobre as cargas, prótons e elétrons. Fala que Benjamin Franklin foi o primeiro cientista que deu o nome para as cargas, que Gilbert falou sobre o campo magnético da Terra. (Tiago)

— Isso daí é outra contextualização. Contextualização sócio-histórica. (Pesquisador)

(Linhas 207-222 E3 C2/E1 C3 G2)

Desta forma, podemos verificar que as informações e inovações eram compartilhadas a todo o momento durante os encontros, dando indícios de formação de CP. Outro indicador de CP verificado foi "Ausência de preâmbulos introdutórios, como se conversas e interações fossem meramente a continuação de um processo em andamento". Abaixo estão inseridos alguns trechos que iniciaram os seus respectivos encontros e enfatizam claramente a presença deste indicador:

- Bom dia. Quero recomeçar os encontros e perguntar logo se algum dos dois [professores] se voluntaria a iniciar? Aquele professor que dá a aula daquele conteúdo que a gente vai trabalhar. (Pesquisador) (linhas 1-3 E1 C1 G1)

- Bom dia. Dentro da proposta que a gente falou, o professor Pedro vai ser o professor responsável por ministrar a aula que a gente vai planejar aqui. O professor Pedro está com turmas do $1^{\circ}$ ano [do EM] e o professor José com turmas de $2^{\circ}$ e $3^{\circ}$. Conversando com ele [professor Pedro], ele disse que finalizou um assunto e agora está fazendo revisão, não é? (Pesquisador) (linhas 1-4 E1 C2 G1)

- Boa tarde, a gente hoje vai começar comentando a aula do Paulo. Eu fiz umas anotações aqui e até uma das coisas que a professora de Portugal [que participou da banca de qualificação] falou do meu trabalho, que é uma coisa que não estamos fazendo tão explicitamente, mas implicitamente está feito. É o seguinte: no estudo de aula tem 
que ter uma questão que a gente vai trabalhar. Uma questão voltada para os alunos. Normalmente, as aulas e as atividades que a gente tem feito, todas elas são voltadas para o mesmo sentido, que é o que vejo. Os alunos não conseguem ver a física no cotidiano, não conseguem ver fora do contexto que a gente apresenta na escola e, também, tem um desinteresse muito grande. Então, nossas atividades é mais contextualizar a física e fazer com que eles se interessem pela disciplina, mostrando que não é só a matemática. É mais ou menos isso que temos feito? (Pesquisador) (linhas 1-10 E3 C2/E1 C3 G2)

Nos encontros formativos, foi notório que não existia uma "retrospectiva" do encontro anterior, o que fez que o encontro tivesse início no ponto em que o outro terminou, como se não houvesse um intervalo entre eles. É interessante que isto ocorreu já no primeiro encontro do primeiro ciclo do G1, pois, dos participantes presentes, o Pesquisador e os professores Moisés e José já haviam participado das atividades de EA que ocorreram no estudo piloto. No G2, já no segundo encontro ocorreu isto, até devido à intensa conversação ocorrida via WhatsApp desde o início da formação deste grupo.

Mais um indicador constatado durante a análise foi "Configuração muito rápida de um problema a ser discutido". Nos dois grupos, foram verificadas a presença deste indicador durante o estudo dos conteúdos, quando o Pesquisador ou algum participante questionava algo, durante a proposição de atividades para a aula de investigação ou ainda nas discussões acerca do ordenamento dos conteúdos, conforme podemos verificar nos trechos abaixo:

— Mas, até isto é interessante a gente ver: será que é interessante falar de dilatação antes de ver os processos [de propagação do calor]? Eu acho que não! Porque, como é que uma coisa vai dilatar? Tem que receber calor! Quais são as formas que ele recebe este calor? (Pesquisador)

- No caso, já está me dando uma ideia para eu chegar por lá [iniciar pelos processos de propagação de calor para depois falar acerca da dilatação]. (Moisés)

- Isso! Da mesma forma como a gente falou no outro ano [estudo piloto] sobre as leis da termodinâmica... É melhor falar isto antes de falar das transformações [térmicas]? $\mathrm{E}$ a gente viu que era mais interessante mudar a ordem do livro, o que ajudou na compreensão dos alunos! (Pesquisador)

(linhas 47-56 E1 C1 G1)

- Pois é, então eu acho que pode começar problematizando essa questão: a queda do objeto. Eu acho que esses desenhinhos simples [aponta para o desenho do planeta feito no quadro]... (Pesquisador)

- É clássico. (João)

— [...] acabam com o argumento de cair para baixo. Já mostra claramente, até outras coisas: porque essa pessoa que não cai. Fala da questão da ação da gravidade. Se for falar, um pouco mais, da gravidade, dá uma comentada na formação do planeta, também. 
E do próprio movimento dele, porque... já que o Sol... a Terra gira ao redor do Sol porque o Sol atrai a Terra. Por que que não se choca? Porque ela está em movimento! (Pesquisador)

- Ela quer ir embora. (Tiago)

- aí pega um crachá. Se você não tem, pode ter um aluno com um colar e um pingente. Fica girando no dedo. Eu não sei se você usa crachá. (Pesquisador)

- E é bom pedir para o aluno. Quando você chega e pede para o aluno, você sente... (Paulo)

- Quebra. (Tiago)

(linhas 884-896 E3 C2/E1 C3 G2)

Esses excertos demonstram o quanto o problema a ser discutido era rapidamente configurado. No primeiro trecho, vemos uma discussão acerca da ordem dos conteúdos a serem ministrados e no segundo, uma discussão acerca do conteúdo em si que seria lecionado, os coeficientes de dilatação. Esta rápida configuração dos problemas foi recorrente em todos os encontros e também é um dos indicadores de formação de CP, segundo Wenger (2008).

O indicador "Saber o que os outros sabem, o que podem fazer e como podem contribuir" foi constatado, embora, na maioria das vezes, de forma implícita. Os dois grupos eram formados por pessoas com um conhecimento aprofundado em Física (Pesquisador graduado em Física, professores formados em Física e mestrandos em ensino de Física que lecionavam Física na educação básica, além de licenciandos em Física) então, era natural que os questionamentos acerca dos diversos conteúdos estudados demonstrassem implicitamente este indicador, visto que estávamos estudando e preparando aulas de Física entre pessoas da área. Isto foi verificado em todos os encontros formativos. Como exemplo podemos citar os trechos seguintes:

- Certo! Quando se fala de calor, aqui em Teresina, todo mundo conhece! (Pesquisador)

— É, mas só relaciona o calor às altas temperaturas! (Moisés)

— Pois é! Então [se dirigindo ao José], quais são estes processos? (Pesquisador)

— Condução, convecção e irradiação [Pesquisador escreve no quadro]. (José)

(linhas 40-43 E1 C1 G1)

- Esta variação sempre é do final para o inicial. O final [escrevendo no quadro], me deixa colocar minúsculo, menos o inicial. Na posição... ele começou onde? Começou aqui e terminou aqui [apontando para a reta graduada, no quadro]. Aqui seria... até outra coisa: "s" aqui é maiúsculo ou minúsculo? Me deixa colocar minúsculo. " $\mathrm{s}_{0}$ " ou "s" o "s" inicial? Pode ser. Pode colocar "s,", pode colocar "s", pode colocar "s", sei lá! 
Mas, o que quer que você use, use sempre a mesma coisa! É isto que eu estou falando, tá? Isto traz menos dificuldades para os meninos [alunos]. Velocidade escalar média é só pegar o espaço e [dividir pelo] o tempo. E velocidade instantânea, qual é a diferença? (Pesquisador)

— A velocidade instantânea é com o tempo tendendo a zero. (Mateus)

—é para determinado instante! (Isaque)

— Em determinado instante! Aí entraria... bom será a palavra: limite! (Pesquisador)

- O limite quando a variação do tempo tende a zero. Alguns livros trazem. Eu não sei se este trouxe. Mas... só que é complicado... eu não sei... (José)

$[\ldots]$

— Eu estava pensando: tem como falar de outra forma? (Pesquisador)

- O que tem que deixar claro é que o espaço [intervalo] de tempo tem que ser pequeno, muito pequeno! Fala isto sem falar do limite... (José)

(linhas 460-479 E1 C2 G1)

Esses trechos elencados demonstram bem que havia uma noção acerca do conhecimento dos demais integrantes do grupo, até por todos estarem envolvidos com a área da Física, quer seja em formação inicial ou no exercício da docência. Outras situações em que este indicador foi verificado, agora mais explicitamente, foi quando o Pesquisador fez questionamentos ou comentários direcionados aos licenciandos acerca do estágio ou aos integrantes do grupo que participaram, também, de algum dos estudos pilotos ou quando um professor questionou outro professor, que era visto como uma referência para os demais do grupo, como podemos ver nos excertos abaixo:

- Bom dia. A gente vai comentar um pouquinho sobre as aulas que ocorreram [dos professores José e Pedro]. Então, a gente vai começar, aqui... os dois aqui [se referindo ao professor José e ao licenciando Isaque] já haviam participado de atividades deste tipo. Isaque em 2016 e o José no ano passado [2017]. (Pesquisador)

(linhas 1-4 E3 C1 e C2 G1)

— Isso! Lembrando que a gente começa... Ei, Timóteo, o que tu acha da definição do campo magnético porque a definição de campo magnético é uma definição complexa, você só vai definir campo magnético, quando você começar a falar de espira, solenoide... (Paulo)

— Tu vai falar ainda força magnética no fio, força magnética em dois fios, corrente para cima ou para baixo? (Timóteo) 
— Não. Não dá tempo! Isso daí entra como exercício, como questão. Não entra porque é isso é aplicação. Aplicação é exercício, gente! É isso que é o problema. (Paulo)

(linhas 514-520 E4 C1/E1 C2 G2)

Outros dois indicadores foram detectados em todos os encontros, que são: "Capacidade de avaliar adequação de ações e produtos" e "Conhecimento local, histórias compartilhadas, piadas internas e risos conhecidos". Estes indicadores se mesclam com alguns indicadores acima comentados, como, por exemplo, quando o participante de um dos grupos fala acerca de sua própria experiência (história compartilhada) ou quando discorda do que fora exposto pelo colega (avaliação da ação ou produto), com exemplos já expostos acima.

Pudemos observar, entretanto, em relação ao indicador "Conhecimento local, histórias compartilhadas, piadas internas e risos conhecidos”, que no G2 houve um ambiente um pouco mais descontraído que no G1. Isto pode ser observado no trecho seguinte:

- Eu fazia parecido com isto, em experimentos de eletrostática, quando eu atritava canudos, coisas assim, no cabelo. (Tiago)

— Tá vendo, foi atritar demais (O professor Tiago é calvo). (Paulo)

[risadas] (Todos)

(linhas 639-642 E2 C1 G2)

O excerto demonstra que ocorreu a formação de um ambiente de amizade, de companheirismo. Em todos os encontros ocorriam as piadas internas e isto tornava o ambiente mais agradável e a interação menos artificial. Também ocorreu, em ambos grupos, o compartilhamento de histórias via WhatsApp. Nos dois grupos, os professores e licenciandos compartilhavam vídeos e materiais instrucionais, bem como faziam perguntas que causavam pequenas discussões e, também, sugeriam atividades para os colegas. Vale salientar que a utilização desta ferramenta (aplicativo de mensagens instantâneas) não cessou com o término das atividades de EA, mas prosseguem até o momento de escrita deste artigo (julho/ 2020) e evidencia, ainda mais fortemente, a presença deste indicador.

O indicador "Capacidade de avaliar adequação de ações e produtos" foi detectado em todos os encontros e se mescla com alguns outros. Este indicador foi bem perceptível em alguns momentos específicos: quando se propunha uma metodologia de ação para a aula de investigação ou a ordem de apresentação do conteúdo e, principalmente, ao comentar acerca da aula observada e fazer a avaliação do método. Este momento é riquíssimo e nos auxiliaram a compreender e ajustar, caso fosse necessário, a metodologia, bem como possibilitou um feedback ao professor que ministrou a aula. Este momento é interessante, pois apresenta um segundo olhar (Hattie, 2009) à ação do professor, o que pode lhe apresentar informações que este desconhecia acerca da sua prática. A seguir, 
alguns trechos que evidenciam este indicador:

- Ele [o professor Pedro] falou que ia ser devagar [a aula] e tal... (Pesquisador)

- Realmente, foi um pouco devagar, pela questão da participação dos alunos. Eu percebi, lá na aula, que os alunos realmente participaram. Ele conseguiu fazer um exemplo no quadro e chamou a atenção dos alunos. E, após este exemplo, ele pediu que os próprios alunos criassem exemplos do conceito que ele passou em sala de aula. Isto até que motivou mais os alunos a fazer, a participar da aula. (Mateus)

(linhas 14-19 E1 C3 G1)

- Certo. (Falando com José) Comparando com os ciclos que a gente fez no ano passado, teve alguma diferença? Para melhor ou para pior. O que é que você achou dos encontros aqui? (Pesquisador)

- Para mim a diferença foi a aplicação dos experimentos, que no ano passado eu não cheguei a fazer. Isto foi bastante proveitoso. Eu gostei da situação, que estava todo mundo (inaudível) absorvendo o conteúdo... sim. A gente basicamente manteve as mesmas discussões sobre o tema até se chegar em um planejamento de aula comum a todos. Eu acho que foi basicamente a mesma coisa que a gente fez e aperfeiçoou mais ainda, digamos assim, por conta da prática. (José)

- A gente teve mais foco. No ano passado a gente ficava mais solto. Parece que agora a gente ficou mais direcionado! (Pesquisador)

- É. As reuniões mantiveram, basicamente, os mesmos componentes. Pelo menos tinha dois ou três que estavam sempre presentes. Diferente do ano passado, que teve muitos desencontros e isto atrapalhou bastante. (José)

(Linhas 50-63 E2 C3 G1)

- [...] Eu anotei algumas coisas aqui, tá certo? Têm algumas perguntas: "os alunos viram o vídeo postado no whatsapp?". Viram. Todos, ou quase todos, viram. "A técnica da tempestade mental propiciou o direcionamento adequado?". Direcionou para a força magnética. Fez a ligação com que o professor queria. Então, foi bem colocado ali. "O ordenamento não tradicional da aula, facilitou a compreensão do assunto?". Aí, a gente vai ver aqui. "Os exemplos dados foram suficientemente ilustrativos?". Sim. "A participação efetiva dos alunos durante a aula foi maior em um determinado momento? Se sim, por quê?". Eu achei que houve, mais ou menos, a mesma participação durante toda a aula. Não teve nenhum momento que chamou a atenção em relação a isto. Então, coloquei nas minhas observações: "o professor entra na sala e os alunos se levantam". (Pesquisador)

- Sim. (Paulo)

- Uma líder da turma faz os alunos ficarem em posição de sentido. Depois de baterem 
continência ao professor, ela pergunta se tem autorização para sentar. Se sim, todos os alunos sentam. Essa daí eu achei bem diferente. Você [se referindo ao professor Paulo] pergunta se os alunos viram o vídeo e questiona coisas como: "por que o fio fica no eletroduto?". Perguntou por que o fio condutor fica no eletroduto e não fica direto na parede, não fica um fio junto do outro, colados os dois, assim, presos [fazendo os gestos com as mãos]. Falou do átomo hidrogênio, da conta de luz. Comentou que o campo magnético não produz trabalho, porque o cosseno do ângulo é zero. Ele dá uma volta, né isso? (Pesquisador)

— Tem a [inaudível] elétrica. (Paulo)

- Então questionou o que era força. Conjugou a equação da força magnética. (Pesquisador)

- Cosseno de noventa [graus] é zero. Força central. (Paulo)

— então, conjugada a força magnética, a força magnética é proporcional a q x v x B, que é diferente de trabalho, que é igual a fvcos $\Theta$. Cosseno de alfa, qualquer coisa. Esse daí é um produto escalar e a força magnética era um produto vetorial. Ele comentou a diferença, deu um exemplo no quadro e explicou a regra da mão direita, utilizando positivo, negativo e neutro. Turma extremamente atenciosa e participativa. Fez uma breve revisão do movimento circular uniforme. Fazia revisão do assunto à medida que ia ministrando conteúdos. Quando precisava de alguma coisa, ele ia e recapitulava aquilo que comentou. Ao final, fez a ligação de questões prévias e respondeu sobre o conduíte, por que o fio estava no conduíte. Mostrou figuras ilustradas. Eu saí e ele não tinha trabalhado as aplicações, que trabalhou nas aulas seguintes, não foi? (Pesquisador)

- Foi. (Paulo)

- Espiras, bobinas e etc. Falou das questões do simulado a pedido dos alunos. Achei interessante isso: ele fazia uma aula mais conceitual, discutindo mais. Aí, chega aquele momento que o aluno pensa: “Pô, o professor não tá dando aula!". Acho que é mais ou menos isso. (Pesquisador)

- Isso. (Paulo)

(linhas 37-78 E3 C2/E1 C3 G2)

Podemos verificar, com base nos trechos acima, que as observações das aulas produzem a capacidade de avaliar a aula, não no sentido de julgar o colega, mas de procurar entender como ocorreu a aula, levando em consideração a prática docente do seu ministrante. Esta compreensão da aula e o feedback dado ao ministrante são partes importantes do EA.

O indicador "Identidades definidas mutuamente" foi facilmente identificado no momento de avaliação do método, conforme podemos verificar nos trechos abaixo:

— Então, me digam aí, já fazendo uma análise aqui do método: O que vocês acharam 
dessas atividades realizadas durante os encontros? (Pesquisador)

- Para mim, foi uma coisa singular esta história de fazer um planejamento coletivo. Mas, eu acredito que... (Paulo)

— Tira da zona de conforto, não é? (Pesquisador)

— Não só tira da zona de conforto, mas cada insight que a gente compartilha, que eu já tentei fazer isto várias vezes com os professores, quando a gente está conversando [...]. Então, foi uma experiência muito importante e isso, eu tento levar para a sala de aula na educação básica, na educação regular e isto causa a ojeriza de alguns professores, não é? "Deixa de querer aparecer", por eu tentar fazer isto. (Paulo)

(linhas 127-142 E3 C3 G2)

- [...] As aulas que a gente planejou com os professores, se fossem vocês planejando, sairiam diferentes? (Pesquisador)

- Sem esta discussão? (César)

— Sim. Você fazendo isoladamente. (Pesquisador)

- Acho que ia ser diferente! (César)

— Seria mais direta? (Pesquisador)

[César balança a cabeça, afirmativamente]

— Isto é fato! E os encontros geraram reflexão sobre sua própria prática de vocês? Eu sei que o estágio... Vocês estão no 2 [estágio observacional], não é? (Pesquisador)

- Sim. (Rebeca)

- Pois é. No próximo, será que alguma sementinha foi plantada para vocês procurarem fazer alguma coisa diferente? (Pesquisador)

(silêncio)

— [falando com a Rebeca] Se causou, o que você procuraria fazer diferente? (Pesquisador)

- A forma! Digamos assim, eu acredito que isto ajudou na própria construção da identidade, de quando você vai planejar a aula. Por exemplo, nas disciplinas pedagógicas, se a gente vai trabalhar um assunto, a gente trabalha o assunto e assiste outros colegas falando de outros assuntos, não é? Então, o contato que você tem é só com estes colegas, a forma como eles planejaram... (Rebeca)

(linhas 108-127 Avaliação dos licenciandos G2) 
Com base nos textos anteriores, extraídos das transcrições dos encontros formativos, podemos perceber que o contato entre os pares fomentou a reflexão e a mudança, ampliando as possibilidades de atuação profissional. Com isto, acreditamos que a identidade, a forma de se ver como professor, também foi modificada.

O indicador "Ferramentas específicas, representações e outros artefatos" foi verificado abundantemente durante o planejamento. Este se evidenciava ao serem utilizados os gráficos, equações, unidades de medida etc. Como se tratava de um grupo nos quais os integrantes tinham formação específica em Física (alguns finalizando o curso de graduação) ou não a tinha (professor Pedro do G1, que é graduado em Química), mas atuava como professor da disciplina, as ferramentas, representações e artefatos para o ensino de Física eram utilizados a todo o instante nas discussões.

E, por fim, o indicador "Discurso compartilhado refletindo certa perspectiva de mundo" também foi verificado ao longo dos encontros, conforme podemos verificar nos trechos abaixo:

— Professor [falando com o Pesquisador], eu só queria comentar uma coisa!

- Diga. (Pesquisador)

— Em relação aos encontros é que... o que eu considero realmente importante destas atividades que a gente faz é que a gente se força a pensar como aluno [do ensino médio]. Pegando o exemplo, por exemplo, do assunto de cinemática, que é um assunto que, para a gente, que já viu muitas e muitas vezes, é simples! Como o senhor [Pesquisador] mesmo falou: você pega o assunto, lê ali rapidamente e já põe na cabeça o seu plano, tudinho! “Ah, eu vou fazer isto, vou fazer isto, vou fazer aquilo!". Mas, às vezes, o que é fácil para a gente como professor, para o aluno, não é. O interessante destas reuniões é que a gente se força a pensar como aluno. "Eu já dei esta aula não sei nem quantas vezes, mas será que tem uma maneira diferente, uma forma mais simples de estar traduzindo isto daí para o aluno?". O que é interessante é isto. A gente se força mesmo a pensar em formas alternativas: um novo método, uma forma de fazer. (Isaque)

(linhas 248-259 E2 C3 G1)

— Então, eu tô falando muito de contextualizar de forma trabalhada para o aluno a possibilidade disso... Eu acho que a gente poderia colocar uma aula visando mais essa parte verificável, por assim dizer! Eu posso dizer: compreender que este conceito está presente no cotidiano, também? (Pesquisador)

- Pois é, mas eu acho que isso daí... eu não vejo como o objetivo da aula. Quando a gente vai introduzir, a prerrogativa é fazer ele [o aluno] pegar logo! Para você introduzir, você vai ter duas opções: da fenomenologia para a teoria. Ou você começar da teoria... (Paulo)

- Para chegar ao fenômeno! (Pesquisador) 
— Eu acho que se partir de teoria para chegar na fenomenologia, você vai ter um pouco mais de dificuldade. (Paulo)

- E vai fazer menos sentido para o aluno. $\mathrm{O}$ aluno pode ser desmotivado até perceber isto! Então, o que o Paulo falou? O que a gente coloca lá como objetivo? Só lembrando que a aula não tem objetivo geral e específico não, pelo amor de Deus! O objetivo da aula é específico. (Pesquisador)

(linhas 542-555 E2 C1 G2)

Podemos perceber que existe uma valorização do conhecimento que o aluno leva à escola e uma preocupação com que o assunto abordado seja inserido em uma realidade próxima à sua vivência. Vale salientar que trabalhamos com a questão norteadora "como contextualizar a Física e fazer com que o aluno se interesse pela disciplina? ". A fala do licenciando Isaque ilustra bem a preocupação que ocorreu ao longo dos encontros em relação a isto. Esta preocupação em aproximar a Física à realidade dos alunos, a nosso ver, facilita o seu ensino e gera um maior interesse no aluno pela disciplina.

Deste modo, com base nos indicadores de Wenger (2008), os quais, durante as reuniões, identificamos 11 dos 14, podemos afirmar que houve a formação de Comunidades de Prática em ambos os grupos. Embora tenham ocorrido apenas 7 encontros no G1 e 9 no G2, os indicadores de formação de CP foram verificados em ambos. Convém salientar que a interação entre os participantes não ocorria apenas nos encontros presenciais: ela ocorria intensamente por meio dos grupos de mensagens instantâneas (WhatsApp). O interesse mútuo pela temática que estava sendo abordada e a vontade de poder pensar acerca da própria atuação, ainda que futura, no caso dos licenciandos, possibilitou que isto ocorresse. Como o objetivo dos grupos era comum a todos os seus integrantes, a formação de CP foi algo que ocorreu de forma espontânea e natural ao longo dos encontros formativos.

Também percebemos que, no início, o Pesquisador assumiu o papel de participante central, coordenando o processo e não ficou definido, a priori, quem assumiria os papéis de participantes ativos ou de periféricos. Era esperado que os professores assumissem o papel de participantes ativos e os licenciandos o de participantes periféricos, o que de fato ocorreu. Mas, apenas os licenciandos da Comunidade de Prática 1 (CP1), anteriormente denominada G1, esboçaram um movimento de sair da periferia da $\mathrm{CP}$, deixando de ser o que Lave e Wenger (1991) chamam de aprendizes periféricos, para através de um movimento denominado pelos autores de participação periférica legitimada, tornaremse mais competentes e se deslocassem para o centro da comunidade. Este foi mais um indício da formação da Comunidade de Prática.

$\mathrm{Na}$ Comunidade de Prática 2 (CP2), anteriormente denominada G2, os licenciandos não esboçaram um movimento no intuito de sair da periferia da $\mathrm{CP}$ e tornarem-se participantes ativos. Eles não se integraram ao grupo tal como ocorreu na $\mathrm{CP} 1$ e os motivos possíveis foram discutidos no $\mathrm{E} 3 \mathrm{C} 3$, como podemos verificar no trecho abaixo: 
- [...] A questão de ter professores de diferentes escolas e haver introduzido licenciandos foi legal? O que foi bom e o que foi ruim? (Pesquisador)

- A proposta foi boa. A questão dos licenciandos, como até o senhor [pesquisador] colocou no começo, a participação deles foi... (Davi)

- Minada! (Pesquisador)

-É. (Davi)

- Não houve a participação deles! Eu acredito que foi uma coisa meio perversa, porque eles entraram mais como expectadores. Por não ter uma percepção, não é nem experiência... Isso. Vou utilizar este termo "experiência". Por não ter uma experiência de sala de aula e, também, eu acredito que o nosso lócus é privilegiado porque a gente está em um mestrado em ensino de física. Então, antes da gente se propor a participar da atividade a gente já tinha, pelo menos desde o final do ano passado [2017] a necessidade de problematizar o ensino de física. Então, juntou a fome com a vontade de comer. (Paulo)

(linhas 201-214 E3 C3 CP2)

Embora o envolvimento dos licenciandos não fora conforme o planejado (tal como ocorreu na CP1), este fato não indica que não ocorreu a formação de CP. Lave e Wenger (1991) afirmaram que, mesmo que o participante novato (o aprendiz periférico), se identifique com a CP, se ele tiver apenas com os conhecimentos básicos sobre o tema estudado na comunidade, continuará na região periférica, na área mais externa da CP. Conforme Wenger (2010) comentou, para que haja este movimento da extremidade em direção ao centro da CP, o aprendiz deverá ter os seus conhecimentos modificados e a sua identidade transformada.

A formação da CP2 ocorreu efetivamente, porém os licenciandos não alcançaram o conhecimento necessário para modificar o seu posicionamento na sua estrutura. Para estes, seria necessário uma vivência (experiência) maior para que pudessem sentir-se mais à vontade para envolver-se nas discussões e atividades da CP. Então, com base no que verificamos na CP1 e CP2, para que os licenciandos pudessem constituir uma relação mais igualitária entre os pares da CP seria interessante que estes possuíssem experiência docente, que poderia ter sido adquirida através do estágio supervisionado, ou se tivessem a oportunidade de participação nas aulas dos professores, como observadores. Desta forma, a contribuição e compartilhamentos seriam mais efetivos e a participação deixaria de ser periférica.

Foram verificadas as três dimensões que delimitam as $\mathrm{CP}$, conforme Wenger (2008): engajamento mútuo, empreendimento conjunto e um repertório compartilhado. Podemos afirmar isto pois os indicadores são as ramificações dessas três dimensões. Verificamos o engajamento mútuo na interação entre indivíduos que se envolveram nas atividades, compartilharam as suas experiências e se dedicaram para que chegássemos 
aos planejamentos das aulas de investigação. O empreendimento conjunto foi o objetivo comum dos integrantes desta CP para aprofundar os conhecimentos na metodologia de Estudo de Aula e melhorar a sua ação docente na escola. E o repertório compartilhado foi verificado ao constatarmos que existia uma preocupação efetiva entre os integrantes das $\mathrm{CP}$ em aproximar os conhecimentos à realidade dos alunos. Para isto, expuseram as suas ações de modo a ampliar as possibilidades dos demais integrantes da $\mathrm{CP}$ atuar, bem como se dispuseram a ser criticados por isto.

\section{Considerações finais}

Em relação à formação de Comunidade de Prática verificamos que as atividades de EA propiciaram que os dois grupos se transformassem em Comunidades de Prática. No total, dos 14 indicadores propostos por Wenger (2008), foram detectados $11 \mathrm{em}$ cada uma das CP. Também foi visto que o Pesquisador ocupava, segundo Lave e Wenger (1991) o lugar Central, os professores, o de participantes ativos e os licenciandos, de participantes periféricos. Na CP1, foi verificado que os licenciandos descreveram um movimento de saída da zona periférica para a zona de participantes ativos, enquanto na CP2 isto não ocorreu, talvez devido à imaturidade e inexperiência dos licenciandos.

Então, de acordo com os dados expostos acima, podemos concluir que o Estudo de Aula pode ser efetivado em Comunidades de Prática e que esta ação pode possibilitar o desenvolvimento profissional dos seus integrantes. A participação em CP proporcionou uma troca mais intensa de experiências e conhecimentos entre os pares e o EA possibilitou a reflexão acerca da própria prática e um aprofundamento nos conteúdos e na preocupação com o aprendizado do aluno, buscando compreender a visão deste e elaborar aulas mais próximas à sua realidade. $\mathrm{O}$ fato de incluir licenciandos nas atividades formativas acrescentou muito às suas formações, sendo uma interessante nova possibilidade formativa para o momento de formação inicial, especialmente se estes já apresentam uma experiência docente.

A articulação entre EA e CP pode contribuir no desenvolvimento profissional dos integrantes das duas comunidades. As adaptações no método que foram realizadas a fim de implementar o EA na realidade local mostraram-se satisfatórias, visto que o planejamento era rígido e o tempo disponibilizado para os encontros era mínimo.

Como o EA em uma perspectiva de formação de CP foi algo inédito na literatura, temos a consciência que a discussão acerca destas temáticas deve ser ampliada, de modo a gerar um conhecimento mais aprofundado sobre os mesmos. Também seria enriquecedor se as aulas de investigação pudessem ser registradas em áudio e vídeo e acompanhadas in loco por mais integrantes dos grupos formativos, o que não fora permitido em nossa pesquisa. Este registro e observação propiciariam mais informações acerca da forma como os estudantes brasileiros, na realidade investigada, adquirem o seu conhecimento e os professores envolvidos no EA poderiam produzir aulas de melhor qualidade.

$\mathrm{Na}$ nossa compreensão as escolas de período integral seriam locais com um bom 
potencial para aplicarmos o EA na perspectiva de CP, especialmente nas escolas em que estão vinculados a Residência Pedagógica, o Programa Institucional de Bolsa de Iniciação à Docência (PIBID) ou que recebem regularmente alunos do estágio supervisionado, visto que os professores teriam um tempo específico para estudo e capacitação e teriam licenciandos presentes para comporem os grupos formativos. Desta forma, tanto os docentes quanto os licenciandos poderiam se desenvolver profissionalmente cada vez mais e o ensino lecionado por estes de maior qualidade e mais próximo à realidade dos seus alunos.

Embora os resultados apresentados tenham sido consistentes, são necessárias novas intervenções desta natureza, de forma a ampliar o conhecimento acerca desta possibilidade formativa e produzir os ajustes para que esta se torne mais efetiva, bem como investigar a sua aplicação em diferentes contextos.

\section{Agradecimentos}

Os autores agradecem aos professores de Física e aos licenciandos em Física que participaram das atividades. Em especial aos professores, que abriram as suas salas de aula e expuseram a sua ação docente in loco na intenção de repensá-la e melhorála. Agradecemos, também, à Secretaria de Educação e Cultura do Estado do Piauí, à Secretaria de Educação do Governo do Estado do Maranhão e às direções das escolas estaduais, filantópica e privada diretamente envolvidas nesta pesquisa, por autorizarem a execução das aulas de investigação em suas salas de aula e a entrada do Pesquisador e demais docentes e licenciandos para a observação das mesmas. 


\section{Referências}

Baptista, M., Ponte, J. P., Costa, E., Velez, I., \& Belchior, M. (2012). Lesson study na formação de professores do $10^{\circ}$ ciclo do ensino básico. In Actas SIEM XXIII - Seminário de Investigação em Educação Matemática (p. 11). APM. http://repositorio.ul.pt/ bitstream/10451/8661/1/12-Baptista\%2c\%20Ponte\%2c\%20Costa\%2c\%20Velez\%2c\%20 Belchior\%20ATAS\%20XXIII_SIEM.pdf.

Baptista, M., Ponte, J. P., Velez, I., \& Costa, E. (2014). Aprendizagens profissionais de professores dos primeiros anos participantes num estudo de aula. Educação em Revista, 30(04), 61-79. http://www.scielo.br/pdf/edur/v30n4/04.pdf

Bardin, L. (2016). Análise de conteúdo. Edição revista e ampliada. Edições 70.

Bonotto, D. L; Gioveli, I, \& Scheller, M. (2019). Lesson study e formação de professores: um olhar para as produções acadêmicas na forma de dissertações e teses. Rev. Educere et educare, 14(32). http://dx.doi.org/10.17648/educare.v14i32.22528

Fernandez, C., \& Yoshida, M. (2004). Lesson study: A Japanese approach to improving mathematics teaching and learning. Mahwan (New Jersey): Lawrence Publishers; Erlbaum Associates.

Fiorentini, D., \& Crecci, V. Desenvolvimento Profissional DOCENTE: Um termo Guarda-Chuva ou um novo sentido à formação? (2013). Form. Doc., 05(08), 11-23. http://formacaodocente.autenticaeditora.com.br/artigo/exibir/13/62/1

Hattie, J. (2009). Visible learning: A synthesis of over 800 meta-analyses relating to achievement. Routledge.

Lave, J., \& Wenger, E. (1991). Situated learning: Legitimate peripheral participation. Cambridge University Press.

Lewis, C. C., Perry, R. R., \& Friedkin, S. (2011). Using Japanese Curriculum Materials to Support Lesson Study Outside Japan: Toward Coherent Curriculum. Educational Studies in Japan: International Yearbook, 6, 5-19. http://files.eric.ed.gov/fulltext/EJ961554.pdf

Mitchell, E. A. (2014). Increasing self-efficacy and quality lesson planning using lesson study with elementary preservice teachers. (Dissertação de Doutorado em Educação). School of Education, University of Mississippi, Oxford - MS (USA).

Murata,A.(2011).Introduction: ConceptualOverview ofLesson Study.In:Hart,L., Alston, A., \& Murata, A. (eds). Lesson Study Research and Practice in Mathematics Education (pp. 1-12). Springer. https://link.springer.com/chapter/10.1007\%2F978-90-481-9941-9_1.

Norwich, B. (2014). Lesson study for assessment: Introduction and guidelines. Exeter: Short Run Press. http://elac.ex.ac.uk/lessonstudymld/userfiles/Lesson\%20Study\%20 final\%20guidebook\%20pdf\%20Sepot\%2014.pdf. 
Passos, C. L. B., Nacarato, A. M., Fiorentini, D., Miskulin, R. G. S., Grando, R. C., Gama, R. P., .. , \& Melo, M. V. (2006). Desenvolvimento profissional do professor que ensina Matemática: uma meta-análise de estudos brasileiros. Quadrante, 15(1-2), 193-219. http://www.apm.pt/files/_09_lq_47fe12e32858f.pdf

Pedder, D. (2014). Prospects for further development of Lesson Study. In: Dudley, P. (ed.) Lesson Study: Professional learning for our time (pp. 145-151). Routledge.

Rodrigues, M. A. (2019). Estudo de aula em comunidades de prática para o ensino de física: Um estudo de caso em Teresina - PI. (Tese de Doutorado em Educação). Faculdade de Educação, Universidade de São Paulo, São Paulo - SP.

Saito, E., \& Atencio, M. (2013). A conceptual discussion of lesson study from a micropolitical perspective: Implications teacher development and pupil learning. Teacher and Teaching Education, 31, 87-95. https://doi.org/10.1016/j.tate.2013.01.001

Santos, V. C., \& Arroio, A. (2015). A formação de professores em comunidades de prática: o caso de um grupo de professores de química em formação inicial. Quím. Nova, 38(1), 144-150. http://dx.doi.org/10.5935/0100-4042.20140234

Soto Gómez, E., \& Pérez Gómez, A. I. (2015). Lessons studies: Um viaje de ida y vuelta recreando el aprendizaje compreensivo. Revista Interuniversitaria de formación del Profesorado, 83(29.2), 15-28. https://dialnet.unirioja.es/descarga/articulo/5319583.pdf

United Kingdom. (2009). Improving subject pedagogy through Lesson Study: Handbook for leading teachers in mathematics and English. Department for Education. Annesley: Clown. http://webarchive.nationalarchives.gov.uk/20130401151715/https:/www. education.gov.uk/publications/eOrderingDownload/Improving $\% 20$ subject $\% 20$ pedagogy\%20through\%20Lesson\%20Study.pdf.

Van Den Bergh, L., Ros, A., \& Beijaard, D. (2014). Improving Teacher Feedback During Active Learning: Effects of a Professional Development Program. American Educational Research Journal, 51(4), 772-809. https://doi.org/10.3102\%2F0002831214531322

Wenger, E. (2008). Communities of practice: Learning, meaning and identity. Cambridge University Press.

Wenger, E. (2010). Communities of Practice and Social Learning Systems: the Career of a Concept. In Blackmore, C. (ed). Social Learning Systems and Communities of Practice (pp. 179-198). Springer. 
Micaías Andrade Rodrigues

${ }^{\circledR}$ https://orcid.org/0000-0003-4566-7872

Universidade Federal do Piauí

Centro de Ciências da Educação

Departamento de Métodos e Técnicas de Ensino

Teresina, Piauí, Brasil

micaias@ufpi.edu.br

Valéria Campos dos Santos

${ }^{10}$ https://orcid.org/0000-0002-1023-9205

Escola Alef Peretz

São Paulo, São Paulo, Brasil

valcampos07@hotmail.com

Agnaldo Arroio

${ }^{\circledR}$ https://orcid.org/0000-0001-9242-5337

Universidade de São Paulo

Faculdade de Educação

Departamento de Metodologia do Ensino e Educação Comparada

São Paulo, São Paulo, Brasil

agnaldoarroio@usp.br

Submetido em 17 de maio de 2020

Aceito em 21 de agosto de 2020

Publicado em 18 de dezembro de 2020 